\title{
Husband's Support for Their Wives in Antenatal Care Visit
}

\author{
Dukungan Suami untuk Istri dalam Kunjungan Pelayanan Antenatal
}

\author{
Awalia Hanifah*, Hadi Pratomo**, Giang Hoang***
}

*Human Resources Development Officer, PT Meiji Indonesia, Jakarta, Indonesia, **Department of Health Education and Behavioral Sciences, Faculty of Public Health, Universitas Indonesia, Depok, Indonesia, ***Faculty of Medicine and Pharmacy, University of Da Nang, Da Nang City, Vietnam

\begin{abstract}
In Cimanggis Primary Health Care, Depok City, the coverage of both the first antenatal care visit (ANC) and the fourth ANC was $99.4 \%$ (2013) and $91 \%$ (2014). The husband support is one of the factors that plays an important role in mothers' ANC visit. This study aimed to assess predisposing, enabling, and reinforcing factors of the husband support towards their wives' ANC visit. This was a qualitative study using a Rapid Assessment Procedure. Five husbands of pregnant women and their wives were recruited as informants. Two midwives from the primary health care were the key informants. Data were analysed using matrix of qualitative data and thematic analysis technique. Results showed that those three factors, meaning that predisposing, enabling and reinforcing factors of the husband were very important in motivating their pregnant wives to do ANC during pregnancy.

Keywords: Antenatal care visit, husband support, pregnant women

\section{Abstrak}

Di wilayah Puskesmas Cimanggis, Kota Depok, cakupan kunjungan antenatal pertama (K1) dan kunjungan ke-4 (K4) sebesar 99,4\% (2013) dan 91\% (2014). Dukungan suami ibu hamil merupakan salah satu faktor yang berperan penting dalam kunjungan antenatal pada ibu hamil. Penelitian ini bertujuan menilai faktor predisposisi, pemungkin dan penguat dari dukungan suami terhadap ANC istrinya dengan menggunakan pendekatan kualitatif dengan desain Rapid Assessment Procedure. Lima suami dan istrinya yang sedang hamil dipilih sebagai informan serta dua bidan puskesmas sebagai informan kunci. Analisis data menggunakan matriks data kualitatif dan teknik analisis tematik. Hasil penelitian menunjukkan bahwa faktor predisposisi, pemungkin dan penguat dari suami sangat penting dalam mendorong ibu hamil melakukan kunjungan antenatal pada saat kehamilan.
\end{abstract}

Kata kunci: Kunjungan antenatal, dukungan suami, ibu hamil

How to Cite: Hanifah A, Pratomo H, Hoang G. Husband's support for their wives in antenatal care visit. Kesmas: National Public Health Journal. 2018; 13 (1): 8-16. (doi:10.21109/kesmas.v13i1.1565)
Correspondence: Hadi Pratomo, Faculty of Public Health Universitas Indonesia, Building D 1st Floor Kampus Baru UI Depok 16424 Indonesia, Phone: +62217863475, e-mail: pratomohadi@gmail.com

Received: July $10^{\text {th }} 2017$

Revised: October $30^{\text {th }} 2017$

Accepted: January $24^{\text {th }} 2018$ 


\section{Introduction}

Antenatal care (ANC) can be defined as the care provided by the skilled healthcare professionals to pregnant women and adolescent girls in order to ensure the best health conditions for both mother and baby during pregnancy. ${ }^{1}$ The purpose of ANC is to support and encourage psychological adjustment to pregnancy, childbirth, breastfeeding, and parenthood; to promote awareness of the social and psychological components of childbearing and their influences on the family; and to monitor the progress of pregnancy to ensure the health and well-being of mother and fetus. ${ }^{2}$

One of the important indicators relevant to maternal mortality is ANC visit. Globally, during 2007-2014 period, only $64 \%$ of pregnant women attended the WHOrecommended minimum four contacts for ANC, suggesting that much more work need to be done to address ANC utilization and quality. ${ }^{2}$ Overall, in Indonesia (2013), the coverage of the first ANC visit (ANC1) was 81.3\% and the coverage of the fourth ANC visit (ANC4) was $70 \%$, specifically in West Java, the coverage of ANC1 and ANC4 was $99.7 \%$ and $93.3 \%$ respectively. ${ }^{3}$

The number of health personnel was 30 persons including 10 midwives and 10 nurses. There were five medical doctors. The number of pregnant women was 1,282 persons and the number of live births was 1,118 . In Depok City, the trend of ANC1 coverage was 97.8\% (2011), 96.2\% (2012), 95.4\% (2013), and 97.7\% (2014). The reported number of maternal deaths in Depok for two years (2013 and 2014) were 17 cases and none of them from Cimanggis Primary Health Care. While, the trend of ANC4 was $93.0 \%$ (2011), 91.3\% (2012), 91.6\% , (2013) and 93.3\% (2014). In Cimanggis Primary Health Care, the coverage of ANC1 was $99.4 \%$ (2013) and 91.4\% (2014), which was the highest coverage in Depok City. ${ }^{4}$ The regional minimum wage in Depok City in 2015 was IDR 2,735,000 (equal to USD 191) per month. ${ }^{5}$

Husband support seems to be a dominant variable related to the behaviour of their wives in attending ANC. A mother with a supportive husband is more likely to have good ANC. ${ }^{6}$ Generally, the husbands have a positive attitude to ANC and delivery care of their wives. However, in reality, not all husbands are eager to encourage their wives to attend ANC except in an emergency situation. ${ }^{7}$

It is important to conduct a study towards predisposing, enabling and reinforcing factors related to husband support toward ANC visit of their pregnant wives in the area. In 2010, a research using Precede-Proceed Model (PPM) was developed to investigate factors related to low visits for ANC services among pregnant women in West Sumatra, Indonesia. ${ }^{8}$ By using the same method, a similar study was conducted in Banke District, Nepal to identify the prevalence and factors associated with the regular use of ANC services among mothers in rural communities. ${ }^{9}$ Another study combining PPM with the Health Belief Model (HBM) and Self-Efficacy theory was conducted at the prenatal clinic of a teaching Obstetrics and Gynecology hospital in Tehran, Iran to investigate the effect of ANC to increase normal delivery among nulliparous women. ${ }^{10}$

Therefore, this study was to explore selected predisposing (knowledge, attitude, belief and norms of the husband related to ANC and delivery), enabling (availability of saving funds and time of attending ANC) and reinforcing factors (support from health personnel, husbands, and families) of the husband in supporting ANC visit by their pregnant wives.

\section{Method}

This qualitative study employed Rapid Assessment Procedure (RAP). ${ }^{11}$ The criteria for selecting informants were a husband whose wife is pregnant between 3-9 months; had accompanied his wife at least one ANC visit at the primary health care and had both complete home address and a mobile phone for easy communication. In addition, he must also be willing to take a part in the study. Five husbands and their respected wives were selected as informants of this study. In addition, two midwives from the primary health care (a midwife coordinator and a midwife staff responsible for maternal and child health program) were also selected as key informants. The total number of informants was 12 persons.

Both husband and wife were recruited in the waiting area of ANC clinic at the primary health care. After they agreed to participate in the study, an appointment with informant was made to conduct in-depth interview according to guidelines developed. Initial interview was conducted at primary health care and later informants were asked about the place where to continue to have an in-depth interview. The following interview usually took place at the informants' home for 5 husbands and their corresponding wives. The health personnel informants from the primary health care were interviewed at the primary health care. Prior to the interview, a poster showing about ANC and the features of ANC visit (poster is enclosed in Appendix 1) was displayed.

Data collection used the interview guidelines which had been pretested. The interview guideline was made based on the aim of the study, which consisted of background of informants, knowledge, attitude, beliefs and norms towards ANC, availability of finance for delivery, availability of husband's time to accompany his wife for ANC, support from health personnel and husband as well as from families. Each interview took place about 90 to 120 minutes. Data were collected from April $1^{\text {st }}$ to May 


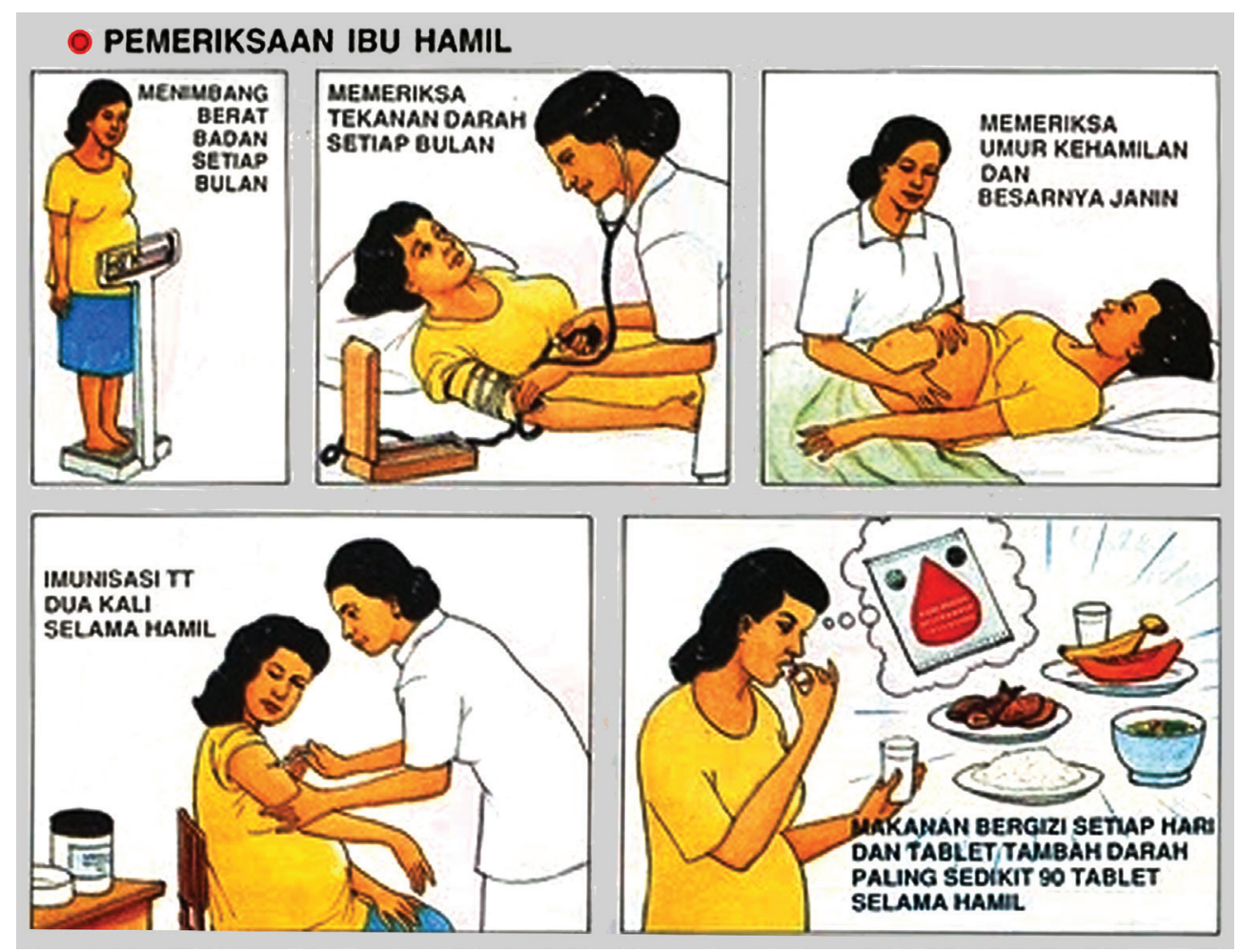

Figure 1. Personal Hygiene of Pregnant Mothers (Self Cleanliness when Pregnant) ${ }^{12}$

$1^{\text {st }}, 2015$. After each informant signing an informed consent, the interview was recorded by a research assistant and field notes were transcribed. As an appreciation after completing the interviews, a token was given to all the informants.

To improve data validity, triangulation of data sources were made using husbands and their wives as informants. In addition, validity of information was also checked using the health personnel at the primary health care as sources of data. After each interview, the data were summarized and the accuracy of information gathered from each of the informants was checked. Records of interviews and field notes were transformed into transcript. Data were reduced using matrix of qualitative data based on specific theme of ANC. The important themes identified were knowledge and exposure of ANC term; recommended frequency and types of examination during ANC; husband's attitude to ANC during pregnancy taken by his wife as well as by family members and neighbors; beliefs and norms related to husband support to their pregnant wives; financial plan of delivery (money saving, insurance, and other investment); availability of husband's time to accompany ANC visit of his wife, advice or encouragement from health personnel and provision of motivation as a mean of support. Table 1 shows the analysis of theme, subtheme, and relevant quotation. ${ }^{3}$

\section{Results}

There were five informants that were husbands of the pregnant wives. The youngest husband was 30 years old, while the oldest was 40 years old. Husband 1 was 38 years old, Husband 2 was 35 years old, Husband 3 was 40 years old, Husband 4 was 37 years old, and Husband 5 was 30 years old. Two informants' wives had their first pregnancy (Husband 1 and 2), the other two of them had the second pregnancy (Husband 4 and 5), and one of them had the third pregnancy (Husband 3). The husbands came from diverse ethnic origins. Two of them were Betawinese, while three of them represented Javanese, Bataknese and Sundanese ethnics. Four of the informants had high school education level, and only one of them had a bachelor degree. In terms of occupation, one of them was handphone merchant, another one was motor bike taxi driver, while the remaining three informants were security guards. In term of household income level, two of the informants had higher income than the regional minimum wage and the other three had less than or equal to the wage. The corresponding pregnant wives' age was between 26 to 35 years. They were in the late period of pregnancy in which two of them were in the sixth month of pregnancy, one in the eighth month and one in the ninth month of pregnancy. The key-informants aged 27 and 39 years old. Both of them attained Academy of Midwifery. One of them was manager, while the other 
Table 1. Theme Analysis of Husband Support for His Wife's ANC

\begin{tabular}{lll}
\hline Theme & Subtheme & Informant Satement/Keywords \\
\hline Knowledge and exposure to ANC term & $\begin{array}{l}\text { Exposure to term } \\
\text { Definition of ANC }\end{array}$ & $\begin{array}{l}\text { None } \\
\text { "This was as a checkup, [it is] also for [increasing] knowledge. The checkup is for }\end{array}$
\end{tabular}

"This was as a checkup, [it is] also for [increasing] knowledge. The checkup is for
[both] the baby and the mother, so we know what their complaints are, whether the [both] the baby and the mother, so we know what their complaints are, whether the
mother and the baby are healthy. [The checkup aimed] at monitoring their health monthly." (Husband 1, 38 years old, Bataknese, bachelor, merchant, the first preg

Agree if the neighbor and family member who were pregnant to take ANC visit

Attitude to ANC

Beliefs and norms related to husband support toward their wives' pregnancy

Agree if the neighbor and family member who were pregnant to take ANC visit

Agreed on ANC visit while his wife was pregnant

Priority of accompanying of his wife to do ANC

Norms related to husband support to his pregnant wife
Belief related to husband support to his pregnant wife

Saving money to prepare for delivery

Availability of saving and other investment as a mean of support

Managing time to accompany his wife for ANC visit

Investment as a means of financial support in emergency situation

Loan funds as financial source in emergency situation
Frequency of ANC visit nancy)

"Within one to seven months [of pregnancy], [the checkup was done] almost once a month. Because the pregnancy had been more than 7 months already, [so the checkup was done] once every two weeks until the time of delivery." (Husband 5, 35 years old, Sundanese, high school graduate, security guard, the second pregnancy) "[During the ANC, my wife] received medicines, vitamin, blood booster, also got tetanus vaccine. Next, [the mother's belly was checked to determine] the heart rate of the baby. In addition, the [wife's] blood pressure and body weight were measured." (Husband 4, 37 years old, Betawinese, vocational school graduate, security guard, the second pregnancy)

"[I] agree with that checkup as it is for her own good. If we have the knowledge of it, we would inform [them] to [take] the checkup" (Husband 5, 30 years old, Sundanese, high school graduate, security guard, the secondpregnancy)

"Yes, I basically agree becauseit (ANC visit) is indeed necessary to let both the mother and the baby be safe, to deliver without problems" (Husband 3, 40 years old, Javanese, high school graduate, security guard, the third pregnancy)

"I will make time for my wife by asking for leave or free day, so then I can mantain both work and my wife taking pregnancy checkupMy work schedule is flexible, which can be arranged by myself."'(Husband 2, 35 years old, Betawinese, high school graduate, motorbike taxi driver, the firstpregnancy)

"Some husbands care, and some other just don't care of their pregnant wives. When I told them (the husbands), they said yes, but [I am] not sure whether they did so.

However, in general, there are more husbands who care [of their wives' pregnancy] than those who do not." (Husband 2, 35 years old, Betawinese, high school graduate, motor bike taxi driver, the first pregnancy)

"In the neighborhood around here, there are variety [of norms], yet majority of the husbands support [their pregnant wives]. There is one unusual case that the husband doesn't care of his pregnant wife." (Wife 2, 29 years old, the first pregnancy) "Well, it is a must [for a husband to accompany his wife for ANC visit]. This was meant for the health of the mother and family, so we should do more care. In case there is something bad happen, the husband [is the one that] would be troubled.

Health is more important, the cost is expensive." (Husband 3, 40 years old, Javanese, high school graduate, security guard, the third pregnancy)

"Yes, [we have] saving. We also use BPJS (National Scheme Insurance), so hopefully it will help us. There is family saving [prepared for just in case the wife has] a cesarean section. We start saving money from the second month [of pregnancy] because previously it (the saving) is usedfor building the house." (Husband 5, 35 years old, Sundanese, high school graduate, security guard, the second pregnancy)

"We have to make it (the saving) sufficient, hopefully it was enough. That is all the responsibility of a husband." (Wife 3, 35 years old, the third pregnancy)

"Well, for practical purpose, [our investment is] just [in form of] motorbike [because] the salary is low." (Husband 4, 37 years old, Betawinese, vocational school graduate, security guard, the second pregnancy)

"Motorbike is included in the investment, isn't it? If so, yes, [we own] a motor bike which can be sold if urgent." (Wife 4, 32 years old, the second pregnancy)

"Usually, the office provides us loan funds for delivery. However, if we still afford [to pay for the delivery cost], we don't need to take the loan. Hopefully, it will be a nor mal delivery." (Husband 4, 37 years old, Betawinese, vocational school graduate, security guard, the secondpregnancy)

"[We may have loan] from [my husband's] office, but I am not sure because my husband never talk about it." (Wife 4, 32 years old, the second pregnancy)

"[Yes] I had ever [made time]. I usually asked my wife whether she had complaints, [then I asked her about] the results of her pregnancy checkup. I often talked to the baby who was in the womb as well." (Husband 3, 40 years old, Javanese, security guard, the third pregnancy)"Yes, I liked to discuss it with my husband as the condition during the pregnancy should be taken care of. He often asked about my condition if I had any complaints." (Wife 3, 35 years old, the third pregnancy) "Usually [my mother] reminds my wife about food and drinking milk. [She] also reminds us about tujuh bulanan (the seventh month traditional ceremony). I was asked to help my wife like washing clothes." (Husband 5, 30 years old, Sundanese, high school graduate, security guard, the second pregnancy)"My parents are talkative with my husband because I am a favorite daughter. The most I remember is that my husband was asked to help me do household chores." (Wife 5, 28 years old, the second pregnancy)

"My wife has been accompanied [by me] from the beginning up to now. If [she was] not accompaniedshe did not want [to go for ANC]. [I] feel I already support [my wife] because I always accompany [her] every visit, so I really should be an alert hus band. My wife also felt my support. The only thing not yet to do is accompanying her at the time of delivery (Husband 3, 40 years old, Javanese, high school graduate, security guard, the third pregnancy)"So far I feel that my husband has strongly sup ported me. I guess he feels the same way because he accompanies me everywhere I go." (Wife 3, 35 years old, the third pregnancy) 
Table 1. Theme Analysis of Husband Support for His Wife's ANC

\begin{tabular}{|c|c|c|}
\hline Theme & Subtheme & Informant Statement/Keywords \\
\hline $\begin{array}{l}\text { Husband provides motivation to } \\
\text { wife for ANC }\end{array}$ & Motivation support & $\begin{array}{l}\text { "If my wife was lazy, I [would] tell her. She ever got lazy once as she was so weak to } \\
\text { go, [she suffered] nausea. That [happened] at early pregnancy. I persuaded her [to } \\
\text { go for ANC], the most important was that I accompany [her] until [we're] going back } \\
\text { home." (Husband } 2,35 \text { years old, Betawinese, high school graduate, motor bike taxi } \\
\text { driver, the first pregnancy)"During the early time of pregnancy, I was unwell as I felt } \\
\text { like I was about to get vomiting constantly. I did not feel like doing anything. But then } \\
\text { I was persuaded [by my husband to go for ANC] by all means. At the end, I agreed to } \\
\text { do so." (Wife } 2,29 \text { years old, the first pregnancy) }\end{array}$ \\
\hline $\begin{array}{l}\text { Advice or encouragement from } \\
\text { health personnel as support }\end{array}$ & & $\begin{array}{l}\text { "Every [ANC] checkup, I went into [the checkup room]. At that time, my wife's body } \\
\text { weight dropped and she coughed. I was told by the midwife at the primary health care } \\
\text { not to smoke near my wife and take care of her food." (Husband } 4,37 \text { years old, } \\
\text { Betawinese, vocational school graduate, security guard, the second pregnancy)"Never, } \\
\text { I never [received any advice from health personnel] because [I] never met the } \\
\text { midwife at the primary health care. Usually, [I] do not [go to the midwife] there (at } \\
\text { the primary health care), but [I go to] the regular midwife." (Wife } 1,26 \text { years old, the } \\
\text { first pregnancy) }\end{array}$ \\
\hline
\end{tabular}

one was executor of the $\mathrm{MCH}$ clinic at primary health care.

Prior to the interview, all informants stated that they never heard a term of ANC. Therefore, before being asked further, both husbands and their wives saw a displayed poster of ANC completely with its description. Then they all were exposed to the ANC term. After that, all of them stated that ANC was similar to what all their wives were doing for routine checkup during the pregnancy.

"This was as a checkup, [it is] also for [increasing] knowledge. The checkup is for [both] the baby and the mother, so we know what their complaints are, whether the mother and the baby are healthy. [The checkup aimed] at monitoring their health monthly." (Husband 1, 38 years old, Bataknese, bachelor, merchant/ businessman, the first pregnancy)

In regard to frequency of ANC visit, the response from both husbands and their wives varied. One of the informant's husband expressed his opinion that one ANC visit was required from the first to the seventh month of pregnancy, while the other one mentioned that during the eighth month of pregnancy, it needed ANC visit once a week. Another husband stated that ANC visit taken once a month was required during pregnancy. None of husbands and wives were able to mention the right number of ANC visits which was four times during pregnancy namely one visit during the first semester, one visit during the second semester and two visits during the last semester.

"Within one to seven months [of pregnancy], [the checkup was donel almost once a month. Because the pregnancy had been more than 7 months already, [so the checkup was done] once every two weeks until the time of delivery." (Husband 5, 35 years old, Sundanese, high school graduate, security guard, the second pregnancy).

ANC visit standard consists of seven checkups including body weighing, blood pressure check, fundal height check, tetanus toxoid immunization, iron tablet distribution, check of sexually transmitted diseases and counseling for preparation of referral services. Most of the husbands were able to mention that there were seven to eight types of checkup, but none of them could mention correctly about the seven components of basic ANC checkup. They mentioned that during ANC, the health provider did the following to their pregnant wives what was done during ANC, such as checking the heart rate of the baby, providing vaccine, and giving iron tablet for the mother. Both husbands and their wives indicated that checking up the condition of the baby was the most important.

"During the ANC, my wife received iron tablets and got tetanus vaccine. In addition, the belly of the mother was checked up, the heart rate of the baby was checked. Lastly, they checked the blood pressure and body weight." (Husband 4, 37 years old, Betawinese, vocational school graduate, security guard, the second pregnancy).

All the informants expressed their positive attitude towards their family members, wives or even neighbor who was pregnant and doing ANC visit. They mentioned a variety of reasons.

"Agree with that exam which is for the benefit of herself. If we do have the knowledge about pregnancy we inform them to have ANC." (Husband 5, 30 years old, Sundanese, high school graduate, security guard, the secondpregnancy)

One of the informants stated that it was to know the baby's condition, another informant indicated that it was for the benefit of mother and her baby. One of the husbands expressed that ANC visit was a must for a pregnant mother to be safe.

"Yes, I agree that the ANC visit is a must to let both mother and baby be healthy without problems." (Husband 3, 40 years old, Javanese, high school 
graduate, security guard, the third pregnancy)

When the husbands of the pregnant women were confronted with a situation in which the schedule of the wife's ANC visit was the same with the work schedule, the attitude taken by all of them was to reschedule or shift schedule with the ANC visit, so the scheduled ANC visit for the wife could take place. Most of the husbands of the pregnant wives prioritized to accompany their wives to go for ANC visit. However, only one husband mentioned that if the situation could not be compromised, he put his work as the first priority.

"I will make time for my wife by asking for leave or free day, so then I can mantain both work and my wife taking pregnancy checkup. My work schedule is flexible, which can be arranged by myself." (Husband 2, 35 years old, Betawinese, high school graduate, motor bike taxi driver, the first pregnancy).

All the informants agreed about husband support toward their wives' pregnancy as it was a norm in their surrounding community where they live in. One of the reasons they mentioned was the fact that several times they saw their neighbor's pregnant wives go for ANC accompanied by their husbands. When they were exposed to the question if there was any husband who did not provide support to his pregnant wife, three of the informants responded that they never found such case, while two of them ever found the case.

"Some husbands care, and some other just don't care of their pregnant wives. When I told them (the husbands), they said yes, but [I am] not sure whether they did so. However, in general, there are more husbands who care [of their wives' pregnancy] than those who do not." (Husband 2, 35 years old, Betawinese, high school graduate, motor bike driver, the first pregnancy)

"In the neighborhood around here, there are variety [of norms], yet majority of the husbands support [their pregnant wives]. There is one unusual case that the husband doesn't care of his pregnant wife." (Wife 2, 29 years old, the first pregnancy)

Although there were variety of reasons, all the informants believed that a husband should have provided support toward their wives' pregnancy. In addition, they believed that husbands must provide support for their wives' ANC visit for variety of reasons. An informant stated that a child was a bearer of future generation to maintain family harmony. Another informant's opinion was that a husband must be ready all the time during the wife's pregnancy. Another reason for supporting the wife's pregnancy was for the benefit of both mother and child's health. An informant strongly expressed his opinion that it was an obligatory chore for a husband to support the wife's pregnancy. Therefore, he had to know the health development of his newborn baby.

"Well, it is a must [for a husband to accompany his wife for ANC visit]. This was meant for the health of the mother and family, so we should do more care. In case there is something bad happen, the husband [is the one that] would be troubled. Health is more important, the cost is expensive." (Husband 3, 40 years old, Javanese, high school graduate, security guard, the third pregnancy)

"There are variety [of norms], yet majority of the husbands support [their pregnant wives]. There is one unusual case that the husband doesn't care of his pregnant wife." (Wife 2, 29 years old, the first pregnancy)

Most informants acknowledged that they had savings to prepare for their wives' delivery. Two informants started to save some money from the the second and the third month of pregnancy. Even one of the informants said that he started to save money even prior to his wife's pregnancy. These statements were strongly affirmed by most of the wives interviewed. Only one informant stated that he never had savings for the delivery due to his limited income that was spent for daily living cost and for his wife's shopping.

"Yes, [we have] saving. We also use BPJS (National Scheme Insurance), so hopefully it will help us. There is family saving [prepared for just in case the wife has] a cesarean section. We start saving money from the second month [of pregnancy] because previously it (the saving) is used for building the house." (Husband 5, 30 years old, Sundanese, high school graduate, security guard, the second pregnancy).

A further discussion was made regarding sufficiency of funds and what happened if they ran out of funds for the delivery. Most husbands reaffirmed that the current saving was sufficient to cover delivery cost because they had started saving money for a long time and they also had the National Scheme Insurance. For those who might feel that their saving was insufficient, he would take money loan as an alternative. Another husband also confirmed in case of emergency they had got to sell his property.

"Insya Allah, hopefully our saving will be sufficient. We also plan to deliver at the primary health care which is usually free, but we need to prepare if something happens. We have already considered what to do if there is an emergency case." (Husband 3, 40 years old, the third pregnancy)

"We have to make it sufficient. Hopefully it was enough. That is the responsibility of a husband." (Wife 3, 35 years old, the third pregnancy)

Apart from saving money, most informants also mentioned that they have assets. These statements were also confirmed by their wives that they had assets such as motor bike (owned by three informants) and gold (owned by an informant). Only one informant did not have any 
asset. The above statement was true as stated by the most of the pregnant wives.

"Well, for practical purpose, [our investment is] just [in form of] motorbike [because] the salary is low." (Husband 4, 37 years old, Betawinese, vocational school graduate, security guard, the second pregnancy)

"Motor bike is included in the investment, isn't it? If so, yes, [we own] a motor bike which can be sold if urgent." (Wife 4, 32 years old, the second pregnancy)

All informants indicated that in case of emergency, they relied on financial assistance from their families. They mentioned that they could get loan from brother or sister, parents and office mates. These responses by the husbands were reaffirmed by their wives that they had families and relatives from whom they could get loan money. However, there was an informant who did not intend to take some loan money because they did not want to make trouble in their families. Only one wife mentioned that she had no idea from whom to to get the loan.

"Usually, the office provides us loan funds for delivery. However, if we still afford [to pay for the delivery cost], we don't need to take the loan. Hopefully, it will be a normal delivery." (Husband 4, 37 years, Betawinese, vocational school graduate, security guard, the second pregnancy)

"[We may have loan] from [my husband's] office, but I am not sure because my husband never talk about it." (Wife 4)

Furthermore, almost all informants indicated that they spent time and frequently discussed with their wives on the schedule for prenatal checkup. However, the topics of discussion among them varied. Some topics included schedule for the next ANC visit, the results of ANC visit, whether any complaints during pregnancy and adjusting the ANC visit with their work schedule. In addition, almost all informants were able to mention the next schedule of ANC visit for their wives. Some of them could see it in the MCH handbook. These responses were confirmed by their wives who indicated that their husbands were willing to spend some time for accompanying them to do ANC visit at the primary health care. There was only one informant who indicated that he rarely discussed the schedule for ANC visit with his wife. He said that the reason was that he felt that the pregnancy of his wife was fine and nothing to worry about.

"[Yes] I had ever [made time]. I usually asked my wife whether she had complaints, [then I asked her about] the results of her pregnancy checkup. I often talked to the baby who was in the womb as well." (Husband 3, 40 years, Javanese, security guard, the third pregnancy)

"Yes, I liked to discuss it with my husband as the condition during the pregnancy should be taken care of. He often asked about my condition if I had any complaints." (Wife 3, 35 years old, the third pregnancy).

One of the informants received advice from the health personnel at the primary health care. However, most informants stated that they never received advice from health personnel at the primary health care when they accompanied their wives to an ANC visit. An informant informed that he did not receive any advice because he rarely accompanied his wife to attend ANC to primary health care. Another informant indicated that he never received any support from health personnel since he just waited outside during his wife's ANC visit. Additionally, the husband did not join the consulting session with the health personnel. These statements were confirmed by the midwives.

"Every [ANC] checkup, I went into [the checkup room]. At that time, my wife's body weight dropped and she coughed. I was told by the midwife at the primary health care not to smoke near my wife and take care of her food." (Husband 4, 37 years old, Betawinese, vocational school graduate, security guard, the second pregnancy)

Some informants indicated that they received support from families especially from the mother or mother inlaw regarding the health of their wives. The support was mostly shown in the form of advice or suggestions, such as taking good care of their wives, reminding their wives to have good nutritional food as well as having ritual ceremony.

"Usually [my mother] reminds my wife about food and drinking milk. [She] also reminds us about tujuh bulanan (the seventh month traditional ceremony). I was asked to help my wife like washing clothes." (Husband 5, 30 years old, Sundanese, high school graduate, security guard, the second pregnancy).

Regarding whether their wives felt lazy for going for ANC visit and kind of motivation given to their wives, most informants expressed that not only did they persuade their wives to attend ANC during pregnancy, but they also encouraged their wives to keep healthy during their pregnancy. Almost all informants stated that they provided motivation to their pregnant women related to nutritional food taken, keeping the body to be healthy and to spoiling their wives. Two of the informants ever experienced a situation in which their wives were lazy to go for pre-natal checkup especially during the early pregnancy, when they were feeling nauseated. During this period, motivation by her husband was persuasion to have the pregnancy checkup for the the health of both mothers and their babies.

"If my wife was lazy, I [would] tell her. She ever got lazy once as she was so weak to go, [she suffered] nausea. That [happened] at early pregnancy. I persuaded her 
[to go for ANC], the most important was that I accompany [her] until [we're] going back home." (Husband 2, 35 years old, Betawinese, high school graduate, motor bike taxi driver, the first pregnancy).

\section{Discussion}

This study used Green's Precede-Proceed model. Precede model was a directive approach to analyze and evaluate behavior after intervention in health education and health promotion during the diagnostic phase. ${ }^{13}$

Role and responsibility of a man especially a husband has strong influence to the health of his wife during pregnancy. One of the strategies to promote support as well as participation of a husband towards the health of his wife is providing correct information and involving them in every effort to improve his wife's health. ${ }^{1}$ The results of this study showed that husbands had motivation in accompanying their wives for ANC visit. They also made good plan for their pregnancy by having financial plan.

A qualitative study by Wijayanti, ${ }^{14}$ in Tebet Primary Health Care, South Jakarta was to explore the husbands' support for their wives' pregnancy and delivery. The results showed that the husbands' knowledge of emergency signs during pregnancy and delivery were minimal. In fact, many of them were unaware of the danger signs. The supportive behavior of the husbands toward their wives' pregnancy and delivery was still inadequate. This was primarily due to the fact of the low knowledge of both pregnancy and delivery among the husbands. ${ }^{14}$

The age of the informants varied from 30 to 40 years. Almost all the informants provided support for their wives' ANC visit. Hence it seems that the age likely did not have an impact on husband support to their wives during pregnancy and delivery. Only one informant did attain a bachelor degree. The way the informant responded to the questions of the interviewer likely depended on the level of education level. The informant with bachelor degree was faster in responding to the questions, more open-minded, and looked more confident in answering the questions of the interviewer.

Most informants worked as security guards, and two of them were working in the informal sectors. Those husbands who worked as security guards with shift were likely able to provide support for their wives due to the fact that their husbands were able to arrange the work shift, so they could provide support or accompany their wives during ANC. It was shown that husbands with income lower than the regional minimum wage was likely not ready and had less initiative to provide support for their wives' pregnancy. This could be seen from the fact that one of the informants with income lower than the regional minimum wage did not know about the ANC schedule for his wife. He was only waiting for his wife's demand to accompany her to go for ANC. The other in- formant from the same income group only accompanied his wife and picked her up from the ANC clinic without being involved in consulting process with the health personnel or accompanying his wife in the checkup room.

Another case was that a husband in the similar income group did not get a chance to save money for providing financial support for his wife's pregnancy. On the other hand, informants with income higher than the regional minimum wage were likely to be ready in providing financial support for his wife's pregnancy. In addition, he also knew in details about preparation needed by his wife during pregnancy and delivery. The role of the husband in providing motivation for his wife to attend ANC visit was also important. This study was limited to a specific place and the informants were selected based on certain criteria. The results of this study could not be applied to other places. During the interview, husbands were accompanied by their wives, therefore, their answers could be influenced by their wives and this might result in biased information. The selected informants were recruited voluntarily, many of people who were asked to be informants refused to be interviewed because they did not want to spend so much time to be interviewed.

\section{Conclusion}

Support from husbands towards ANC visit for the wives in the study is considered good due to the fact that these husbands are aware of the need to provide motivation to their wives for taking ANC, the need to have ANC visit for their wives and the need of making financial plan for the coming delivery. However, the husbands do not accompany their wives for ANC.

The predisposing factors related to support of the husbands for attending ANC include their husband's knowledge of and attitude to ANC. In addition, it also includes beliefs and norms relevant to ANC. The husbands are fully aware that it is some kinds of obligation to provide support for their wives to take ANC during pregnancy. The norms and habits of husband's ethnical background likely affects the husbands in providing support to their wives for ANC. These norms provided some kinds of guideline in the behavior of their husbands in giving support to their wives for ANC.

The enabling factors are meant availability of funds (saving) and time. Not all the husbands are ready financially for the coming delivery of their wives. While, the time availability refers to husbands who are willing to spend some of their time to accompany their wives for the ANC visit. The husbands participating in this study are generally willing to spend time to accompany their wives in attending the ANC at the primary health care.

The reinforcing factors are health personnel as well as family support for taking ANC visit. Support given by 
both husband and families seem to have a positive effect on the pregnant mothers in taking ANC visits. Advice from primary health care are rarely reclined, instead the wife obtained from the practicing midwife.

\section{References}

1. World Health Organization. WHO recommendations on antenatal care for a positive pregnancy experience [Internet]. Luxembourg: World Health Organization; 2016. p. 95-98. Available from: http://apps. who.int/iris/bitstream/10665/250796/1/ 9789241549912-eng.pdf

2. World Health Organization Regional Office for Europe. Essential antenatal, perinatal and postpartum care [Internet]. World Health Organization; 2002. p. 23. Available from: http://www.euro.who.int/ _data/assets/pdf_file/0013/131521/E79235.pdf

3. Kementerian Kesehatan Republik Indonesia. Riset Kesehatan Dasar 2013. Jakarta: Kementerian Kesehatan Republik Indonesia; 2013. p.170-1.

4. Dinas Kesehatan Depok. Profil kesehatan Kota Depok tahun 2014 [Internet]. Depok; 2014. [cited 2017 Jun 20]. Available from: http://dinkes.depok.go.id/wp-content/uploads/PROFIL-KESEHATAN2014.pdf

5. Gubernur Jawa Barat. Keputusan Gubernur Jawa Barat Nomor : 561/ Kep. 1746-Bangsos/2014 tentang perubahan atas Keputusan Gubernur Jawa Barat tentang upah minimum kabupaten/kota di Jawa Barat tahun 2015 Bandung: Pemerintah Daerah Jawa Barat; 2014. p. 9.

6. Gamelia E, Sistiarani C, Masfiah S. Determinan perilaku perawatan kehamilan. Kesmas: National Public Health Journal. 2013; 8(3): 133-8.

7. Kwambai TK, Dellicour S, Desai M, Ameh CA, Person B, Achieng F, et al. Perspectives of men on antenatal and delivery care service utilization in rural western Kenya: a qualitative study. BMC Pregnancy Childbirth.
2013; 13(1): 134.

8. Agus Y, Horiuchi S. Factors influencing the use of antenatal care in rural West Sumatra, Indonesia. BMC Pregnancy Childbirth. 2012; 12(1): 9.

9. Paudel RK, Thepthien B, Hong SA. Factors related to regular use of ANC services among mothers of children under one year of age in rural communities of Banke District, Nepal. Asian Pacific Journal of Health Science. 2016; 3(3): 216-22.

10. Ghofranipour M. The effect of precede-proceed model combined with the health belief model and the theory of self-efficacy to increase normal delivery among nulliparous women. Procedia - Social and Behavioral Sciences [Internet]. 2012; 46(4): 187-94. [cited 2017 Jun 28]. Available from: http://dx.doi.org/10.1016/j.sbspro.2012.05.091

11. Scrimshaw S, Hurtado E. Rapid assessment procedures for nutrition and primary health care: Anthropological approaches to improving programme effectiveness [Internet]. Latin American Center Reference Series (USA). v. 11. United Nations University; 1987 [cited 2017 Jun 16]. 70 p. Available from: http://agris.fao.org/agris-search/ search.do?recordID=XF19900021532

12. Widyawati R. Buku adaptasi fisiologi kehamilan. Available from: http://tokoalkes.com/blog/personal-hygiene-pada-ibu-hamil

13. Green LW, Kreuter MW. Health program planning : An educational and ecological approach [Internet]. McGraw-Hill; 2005 [cited 2017 Jun 20]. Available from: http://library.wur.nl/WebQuery/clc/1769237

14. Wijayanti R. Studi kualitatif tentang gambaran perilaku suami terhadap kehamilan dan pertolongan persalinan istrinya di wilayah puskesmas kecamatan tebet tahun 2007 [Internet]. Depok: Universitas Indonesia; 2007. Available from:http://lib.fkm.ui.ac.id/opac/id/template.jsp?inner $=$ detail.jsp?id $=53564 \&$ lokasi $=$ lokal 